\title{
The Position of Convicted Persons during their Stay in the Correctional Facility and the Implementation of International and European Law in Correctional Institutions in Kosovo
}

\author{
Prof. Ass. Dr. Arif Riza \\ Email: arif.riza@uni-prizren.com
}

\author{
Doi:10.5901/mjss.2016.v7n3p282
}

\begin{abstract}
In this project $i$ have tried to describe the position of the convicted persons during their stay in correctional institutions and the implementation of International and European law in these correctional institutions in Kosovo. So first of all Kosovo's legislation on the execution of criminal sanctions, such as cases of postponing the commencement of execution of imprisonment, accepting of convicted persons in correctional institutions placement, food and clothing, the rights of convicted persons during their stay in the correctional institutions. Implementation of international conventions, especially the United Nations Rules for the Protection of Minors, who are deprived of freedom, the states members should take educational measures for persons serving prison a sentence. Implementation of European Law relating to the rights of persons serving prison sentence, such as the recommendation of the Committee of Ministers of the Council of Europe for protection of prisoners who are foreign citizens, because these people have different language and culture from most prisoners who are citizens of the country where they are serving a sentence. Recommendation of the Committee of Ministers of the Council of Europe on behavior towards dangerous prisoners, where even though this category of prisoners are dangerous, still forbidden to use inhuman methods against them. Resolution of the Committee of Ministers of the Council of Europe for short-term treatment of young convicted persons up to the age of 21 , where if it comes to the punishment of these people, the state is responsibility to put them in special correctional institutions and special care.
\end{abstract}

Keywords: Execution, Punishment, Corrective, Persons, Sanctions, Detention, Imprisonment.

\section{The Position of Convicted Persons during their Stay in the Correctional Institution and the Implementation of International and European Law in Correctional Institutions in Kosovo}

The commitment of the criminal acts with which violate juridical order and damage the vital goods of the human and society, ensues penal sanctions, according to the Penal Code of Kosovo the sanctions are principal punishments, alternative punishments and accessory punishments and juridical reproof (The Penal Code of Kosovo 2013, Art. 42). The principal punishments are: punishment of life long imprisonment; punishment of imprisonment; punishment of a fine (The Penal Code of Kosovo 2013, Art. 43). Certainly the enunciate of the punishments consist of limitation of freedoms and certain rights which are protected by law, but the same can be limited or can be taken in cases provided by law. The execution of the penal sanctions represent the most important phase in which starts the implementation of penal sanction, respectively the punishment, hereupon it's very important to determine the purpose of punishment. The purpose of the punishment according to Penal Code of Kosovo is determined in article 41 , where the purpose of the punishment is to prevent the perpetrator from committing criminal offenses in the future and to rehabilitate the perpetrator; to prevent other persons from committing criminal offenses; to provide compensation to victims or the community for losses or damages caused by the criminal conduct; and to express the judgment of society for criminal offenses, increase morality and strengthen the obligation to respect the law (The Penal Code of Kosovo 2016, Art. 41).

From the lawful determination of purpose of the punishment comes out that Penal Code of Kosovo, has not retributive or revenger character against perpetrator of the penal act, but it has preventive character, special preventive and general preventive.

In realization of the purpose of the punishment during the phase of execution of the punishment has to be respected some basing principles which are: the lawfulness principle, the principle of humanity, the principle of holding the common punishment with imprisonment, the principle of individualization etc (Halili 2005, 207). The reeducation and reintegration purpose of the punishment determines also by The International Pact for Civil and Political Rights,(Approved and opened for signature, ratification and adhere by General Assembly with its Resolution $2200 \mathrm{~A}(\mathrm{XXI})$ date $16^{\text {th }}$ of December 1966), where in article 10.3 it determines that "The Retributive System- Corrective contains a treatment of the convicts that has essential intention of their reeducation and reintegration in society. The minor wrongdoers should be 
divided from adults and have to submit a regimen in order to adapt their age and juridical position" ( The Social Pact for Civil and Political Rights, General Assembly of UN, 1976).

We'll be concentrated on two first main punishments, so punishment of life long imprisonment and punishment of imprisonment. Inasmuch as the purpose of the punishment consist of rehabilitation and reintegration of a convict with intention to return to the society as a capable person to live in conformity with social rules, then to achieve this intention the convict has to submit a adequate treatment inside the retributive institutions. "For execution of the punishment of imprisonment or punishment of life long imprisonment is necessary to exist a almighty and executive decision of competent court ( article 6 of Law on execution of penal sanctions of Kosovo LEPSK), (Law on execution of penal sanctions of Kosovo 2013, Art. 4).

In this article it's talking about for the commence of the execution of the penal sanction. This article says:

1. The execution of a penal sanction shall commence when the decision by which the penal sanction is imposed becomes final and there is no legal impediment to the execution of the penal sanction,

2. The execution of a penal sanction may commence before the decision by which the penal sanction is imposed becomes final only exceptionally in the cases when it is expressly provided by law (Law on execution of penal sanctions of Kosovo 2013, Art. 6). As a competent court for implementation and organization of the execution of imprisonment punishment is the basic court where the residence or where the convicted person lives.

"The execution of penal sanctions shall aim at the re-socialization and reintegration of the convicted person into society and prepare him or her to conduct his or her life in a socially responsible way. The execution of penal sanctions shall also serve the purpose of protecting society by preventing the commission of further criminal offences and restraining others from committing criminal offences" ((Law on execution of penal sanctions of Kosovo 2013, Art. 3). If the convicted is free the basic competent court shall order the convicted person in writing to report to the correctional facility to serve the sentence of imprisonment or life imprisonment on a specific day (article 6 Law on execution of penal sanctions of Kosovo). About the period of time between of 8 days some authors have thoughts that to the convicted shall be given a least 15 days to have enough time in order the convicted to dissolve different family things and obligations. While provisions of law on execution of the penal sanctions in Kosovo, "the period of time between of acceptance of the order and the appearance shall nt be less than eight (8) days and more than fifteen (15) days (Law on execution of penal sanctions of Kosovo 2013, Art.16, Par. 2).

The Basic Court is the organ who gives all information to the correctional institution of the convicted person who should be delivered to the correctional institution. The case of the convey expenses of the convicted person from the court to the correctional institution or from other place to correctional institution, are regulated by articles 10 and 19 of LEPSK. In these articles it's said:

1. "Resources for the execution of penal sanctions shall be provided by the budget of the Republic of Kosovo.

2. The convicted person shall not pay the costs of executing a penal sanction, unless otherwise provided by law (Law on execution of penal sanctions of Kosovo, 2013, Art. 10).

Article 19 says:

1. "The correctional facility shall compensate the convicted person for public transportation expenses from the place of permanent or current residence of the convicted person to the correctional facility.

2. The convicted person shall pay the expenses of being brought forcibly to the correctional facility, (Law on execution of penal sanctions of Kosovo, Art. 19).

\section{Cases of Postponing the Start of Execution of Sentence of Imprisonment}

Often can happen in daily life that the convicted person who received the call to be presented in a correctional facility, presented various difficulties or obstacles and because of this it is foreseen the possibility that an imprisoned may apply for postponement of execution of sentence of imprisonment against him. This delay can be done for various reasons, such as health reasons, family, social, contracting, materials etc.. However, these delays must be justified, eg if it comes to health reasons such as serious illness, the person concerned must submit a medical report, or cases of pregnancy. The reasons or causes of the postponement of execution of sentence of imprisonment are defined clearly and precisely in LEPSK th, respectively, in Article 20.

"Delaying the start of the sentence of imprisonment is initiated by request or prayer of the convicted person within 7 days of receiving an order for serving prison sentence (Law on execution of penal sanctions of Kosovo 2013, Art. 21).

Convicted person besides the supplication, should present the evidence and testimonies to the court justified the reasons for seeking delay start execution of a sentence of imprisonment. Supplication of the convicted person decides the chairman of the executive court. 
If the supplication is rejected, the convicted person has the right to address an appeal to the president of the higher court within three days. Such appeal suspends the execution of a sentence of imprisonment" (Halili 2005, 214). "Chairman of the competent basic court may deny an application for postponement of execution of sentence of imprisonment if later finds that there were no reasons or the causes of the postponement of execution of sentence of imprisonment" (Law on execution of penal sanctions of Kosov02013, Art 28).

According to the LEPSK the postponement of the execution of sentence of imprisonment at the latest can take up to three years and here we're dealing with cases of pregnant women, and in other cases different daily life that delay could be 3 months, 6 months, etc (Law on execution of penal sanctions of Kosovo 2013, Art. 20, Par. 1, Clause 2).

\section{Acceptance of Convicted Persons in Correctional Institutions}

Law on Execution of Criminal Sanctions of Kosovo (LEPSK), Article 31, paragraphs 1 to 4, have prescribed the procedure for admission of persons in correctional institutions including the obligations of officials to make notification of convicted persons regarding to their rights such: control and medical report on health, then notify in writing the rights and duties if they do not read or write, then the convicted person must be notified orally and be notified in the language of prisoners, and notified to the house rules etc. But first, when the convicted person in a correctional facility comes firstly will be verified his identity, the basis for imprisonment and then start other procedures.

\section{Placement, Food and Clothing}

Placement of prisoners to serve sentences should answer the most basic conditions for a normal life. If he or she is the foreign person should be given the opportunity by telephone or in writing to notify the diplomatic representative or the relevant office of his state (Law on execution of penal sanctions of Kosovo 2013, Art. 33, Para. 1). The placement of prisoners in correctional institution should consider these factors: physical health, mental health, age, sex (Article 33 of LEPSK). Such separation is usually done with the purpose of more successful reeducation of the convicted person. Important issues are not only dwelling conditions for the convicted, but also food and clothing. Food should be healthy and prisoners are entitled of three daily rations of food (Law on execution of penal sanctions of Kosovo 2013, Art. 39). But clothes should fit the season and weather conditions (Article 41, paragraph 1 and 2 of LEPSK).

All these above mentioned services are free for the detainees. An important instrument of international present Standard Minimum Rules of the UN, for the Treatment of Prisoners (approved by the Economic and Social Council in 1957), which represent the principles and minimum rules to be observed in the formation of the penitentiary treatment the prisoners.

These rules include: the registration of prisoners, the division into categories, the prison facilities. Personal hygiene, food, medical services, etc (Halili 2005, 283).

Placement, food and clothing of prisoners is also regulated by the European Prisons Rules, where these rules clearly define the obligations of states to ensure the conditions for staying, clothing and hygiene for all the prisoners, in order to address with dinity and to achieve the purpose of punishment (European Prisons Rules, European Council , 2006). According to an Assessment Report of the Organization for Security and Co-operation in Europe MISSION IN KOSOVO, 2010, on conditions in detention centers in Kosovo, results that in general, the material conditions in detention facilities are satisfactory, but a number of things could be improved, mainly regarding size and capacity of cells. This situation could be improved by sufficient reducing the number of people in the cells, ensuring that their size to be in accordance with international standards. Other concerns include poor ventilation, toilets and shower dysfunctional places in some of the facilities, as well as the poor state of repair of some objects (OSCE, mission in Kosovo, Assessment Report, 2010). Although this report refers to the conditions in detention centers, of course that is a clear indication of the situation in which are the penitentiary, given that detainees should have the conditions and treatment as those convicted.

\subsection{The Rights of Convicted Persons during their Stay in the Correctional Facility}

Modern penitentiary systems are using a range of different tools to achieve the greater success in the process of reintegration and rehabilitation of convicted persons. Today, prisoners enjoy a range of rights, which are protected by various international legal acts.

"The main rights of prisoners are: the right to work, right to reward work, the right of daily rest, the right of weekly and annual rest, the right of health and social protection, the right of education and training, the right of receiving visits, the right to exchange letters, the right to receive packages, the right to appeal and complaints, the right of inform, the right 
to practice religion "(Halili 2005, 2017).

Besides of these rights which are provided by different articles of the LEPSK, there are some benefits to prisoners. "These benefits are earned with work, with commitment, by achieving specific results and good behavior during different activities. Benefits as a tool and a method of rehabilitation and support and have found wide application in penitentiary practice in many countries As a known benefit is the extension of the right to receive visits, etc. " (Halili, 1997, 151-170). We will not stop in analysis of the rights of prisoners because such a thing will be analyzed the following international legal acts.

\subsection{The United Nations Rules for the Protection of Minors, who are Deprived of Freedom}

Considering the discrimination and maltreatment of children in many countries of the world "General Assembly of the UN (UNICEF) in 1990 paid attention and special attention to minors deprived of their liberty and so at this time" concluded rules that belong to this category of prisoners, one of such rules is the "Convention for the protection of children's rights (UN-Convention 1989, Art. 34), the European Convention for the protection of human rights. Through these rules the United Nations regulated exceptionally important issues, as are stated that deprivation of liberty of minors should last as short as possible, the time of the appeal proceedings to be shortened, to enable easy visits, they need to be closer to the family, during the execution of the sentence against minors must be respected all the rules, international standards but also legal provisions that regulate such matters. The convicted minors in serving a sentence should not stay in the same place or cell with adults, so they should be visited frequently. Disciplinary punishment should be defined clearly and procedures and tools that are applied to minor delinquents, and the guard of the Penitentiary for Minors must not carry weapons etc. The minor must have the right to appeal against any action taken against him"( Commissione federale d'esperti per la protezione dei minori in caso di rapimento, 2016). It brought special regulations for the protection of children, whose freedom was removed by courts' decisions, demanding special provisions for this category (General Assembly of UN Resolution 45/113, 1990).

Considering the special position of minors as a result of their psycho-physical development, it is also envisaged a special treatment for them when they come into conflict with the law.

To regulate the procedure for minors and measures and punishment which may be imposed on them, in Republic of Kosovo, there is a Code of Justice for Minors, which regulates in detail the position of minors in criminal proceedings and the execution of measures and a sentence of imprisonment for minors (Code of Justice for Minors 2010). In Code of Justice for Minors, Article 85 defines the aim and the method of execution of the educational measures to minors, stating that:

$\checkmark$ "Educational action is executed by respecting the personality and dignity of the minors, encouraging their physical, moral and intellectual development and protecting their physical and mental health.

$\checkmark$ Educational Action is executed based on an individual program, adapted as much as possible according to the personality of the minor and prepared in accordance with modern achievements of knowledge and experience.

$\checkmark$ The Individual Program is prepared on the basis of a inclusive analysis of the special characteristics of the child, causes and the type of crime and other forms of behavioral difficulties, as well as level of education, development of the child and the circumstances of his life family.

$\checkmark$ Individual program includes motivating instruments that are adapted to the personal characteristics of the minor, enrollment in education and professional training, activities of leisure, activity with parents, adoptive parents, guardian or other members of the family of the child and other ways of influence on minors (Code of Justice for Minors 2010, Art. 85)

Undoubtedly, since the definition of purpose and the method of execution of educational measures and punishment for minors, it seems clear the purpose for rehabilitation, reeducation and risocialization of minors, by treated with dignity, and using proper educational treatment, the minor to be prepared in the future to live in accordance with legal and moral norms, and thus avoid the risk to conduct a criminal offense again

\subsection{Recommendation of the Committee of Ministers of the Council of Europe for Protection of Prisoners who are Foreign Citizens}

This recommendation was approved in 1984 and the alterations and amendments to all categories of the Council of Europe in 2006 (Jenaer Symposium 2008, 9-11), with it is regulated position and protection of the rights of prisoners who have foreign citizenship. According to this recommendation, any foreigner who is in detention or imprisonment must be given the opportunity to realize specific requirements. 
"After that these people are in a foreign country, where other language is spoken, where there's other culture for the convicted person, then he should be given the opportunity to associate with other prisoners who have the same nationality. Another a very important issue is that foreign convicted person should be provided an interpreter, so that can realize his rights without no problem that have as a convicted foreigner. He or she can also be visited by diplomatic or consular representative of his country. In order to have a successful reeducation and resocialization it's needed that someone from prison's staff to recognize the language of foreign prisoner" (Popovski and Serrano 2011). The care of the International Community and especially the member states of the European Council on Foreign prisoners were noticed in the documents issued by the Committee of Ministers of the aforementioned organ (The recommendations of the Council of Europe CM / Rec(2012), 2012).

\subsection{Recommendation of the Committee of Ministers of the Council of Europe on Behavior towards Dangerous Prisoners}

This recommendation was approved in 1982 and amendment and supplement with the Recommendations of the Council of Europe of 2006 (Des Ministerkomitees, $C M / \operatorname{Rec}(2012) 5$, 2012) with this are regulated issues of organization, operation against dangerous convicted persons as a special category of convicted persons. According to this recommendation, even though dealing with dangerous convicted persons, however this does not mean that it is permissible use of force in an uncontrolled way and without any restrictions. Usually instruments and actions must be commensurate with the needs that arise in various penitentiary institutions (Committee of Ministers, Recommendation CM/Rec.,(2014), 2014).

Unfortunately in a large number of countries even in very democratic states methods of violence are used during the investigation and also during the sentence. In Kosovo after the 1999 war, international supervision of UNMIK, and after the Declaration of Independence were built high security prisons with international standards, it can be said we have respected the mentioned above conventions for serious offenses prisoners. However from Kosovo's prisons have escaped dangerous convicted persons (footnote will come from Dubrava prison and there is no need to translate).

\subsection{Resolution of the Committee of Ministers of the Council of Europe for short-term treatment of young convicted persons up to age 21}

"This resolution was approved in 1966 and amended and supplemented in 2008 (Des Ministerkomitees des Euriparates, Empfehlung Rec $(2008) 11,2008)$ and other Conventions and Recommendations are counted in the first part of this recommendation (see footnote above).

From its title we can see that this resolution regulates the treatment of young convicted persons, until the age of 21 who are sentenced to short-term of deprivation of liberty. If it comes to the application of this penalty, then to the minor convicted person this measure should be shorter and its execution must be done in special institutions and should be done in such a way that there are no negative consequences in physical and mental development of minor convicted person (Des Ministerkomitees des Euriparates 2008). In this recommendation also includes basic principles and general principles for protecting the rights of minors without being insulted because of their age. In this recommendation are made also categorizations of minors. In Kosovo is a number of minors serving the sentence (footnote will bring in later).

\section{Conclusion}

From all this that elaborated so far, we can see clearly the major changes that have occurred in the penitentiary systems of now days. During the historical development the penitentiary system was being advanced together with other social advancements. Initially the sentence was very harsh and its purpose was repressive against the person to whom was applied.

Only after a long time passed of social development the character of punishment changed from repressive punishment in that preventative punishment. Saying better these rules were improved from international organizations such as the United Nations and especially by the Council of Europe. Our focus for this topic is based not only on the national jurisdiction, but also in the international (conventions) global and regional character. The fact of approval of the international conventions and respecting them regarding to the position of prisoners is not only national but also international issue. A number of acts are only recommendations, so do not imply directly a legal obligation for states, so there should be a moral obligation so indirectly to respect these standards, rules and regulations, for humanitarian and human causes. However, do not forget the fact that even though the states provide with their national legislation 
respecting the rights of prisoners, but there are rare cases of violations and abuses against the basic rights of convicts, so, the fact is different from the formal side. This is proven by various reports of national and international as well as the large number of complaints against the violators of these rules .... (I'll have footnote here).

\section{References}

Dr.Ragip Halili, Penologjia, Prishtinë, 2005;

Dr. Rexhep Gashi : E drejta nr. 1/2005;

Dr. Ismet Salihu, E Drejta Penale Ndërkombëtare, Prishtinë, 2005;

Dr.Ragip Halili, Beneficionet si masa të rëndësishme të riintegrimit të personave të dënuar, Prishtina, 1997.

Dr. Ismet Salihu, E drejta penale për të mitur, Prishtinë 2005;

Komentari i Kodit Penal te Kosovës, Dr,Ismet Salihu, Hilmi Zhitija ,Fejzullah Hasani, Prishtinë 2014;

Kodi Penal i Kosovës, Nr. 04/L-082, Prishtinë 2013;

Kodi i Drejësisë për të Mitur, Prishtinë 2010;

Ligji mbi ekzekutimin e sanksioneve penale i Kosovës Nr. 31/28 Gusht 2013, 04/L-149

Rregullat Evropiane të Burgjeve, Këshilli $i$ Evropës, 2006, http://www.coe.int/t/DGHL/STANDARDSETTING/PRISONS/EPR/EPR Albanian.pf;

Pakti Social për të Drejtat Civile dhe Politike, Asambleja e Përgjithshme e Kombeve të Bashkuara, 1976 http://www.unmikonline.org/ regulations/unmikgazette/ 03albanian/ Ahri/ACovenant CivilPoliticalRights.pdf;

Raporti Vlerësues të Organizatës për Siguri dhe Bashkëpunim në Evropë MISIONI NË KOSOVË, Kushtet në Qendrat e paraburgimit në Kosovë, Prishtinë, 2010 http://www.osce.org/sq/kosovo/73846?download=true; http://www.hrweb.org/legal/cat.html; http://www. uncjin.org/Laws/prisrul.htm; http://www.unicef.org/republicadominicana/english/protection_15759.htm;

After oppression: Transitional justice in Latin America and Eastern Europe Edited by Vesselin Popovski and Mónica Serrano 2012. Retrievet from: http://portal.coe.ge/downloads/European\%20Prison\%20Rules.pdf;

Europäische Grundsätze Für die vonSanktionen und Massnahmen Betroffenen Jugendlichen Straftäter und Straftäterinnen. Empfehlung Rec (2008)11, Des Ministerkomitees des Euriparates vom 5 November 2008. Retreived from: https://wcd.coe.int/com.instranet. InstraServlet?command=com.instranet.CmdBlob; http://www.echr.coe.int/echr/Homepage_EN; http://www.coe.int/t/dghl/standard setting/prisons/Rec(2010)1\%20German\%20version.pdf. 